\title{
OPEN
}

\section{Author Correction: Genome-wide identification of Arabidopsis long noncoding RNAs in response to the blue light}

\author{
Zhenfei Sun, Kai Huang, Zujing Han, Pan Wang \& Yuda Fang \\ Correction to: Scientific Reports https://doi.org/10.1038/s41598-020-63187-1, published online 10 April 2020
}

This Article contains errors in the Reference list. References 28 and 29 are incorrectly listed as references 30 and 31 respectively. As a result, references 30 and 31 are listed incorrectly as references 28 and 29 . The correct references $28-31$ are listed below as references 1-4 respectively.

1. Kong, L. et al. Cpc: Assess the Protein-Coding Potential of Transcripts Using Sequence Features and Support Vector Machine. Nucleic Acids Res. 35, W345-W349 (2007).

2. Sun, K. et al. Iseerna: Identification of Long Intergenic Non-Coding Rna Transcripts from Transcriptome Sequencing Data. BMC Genomics. 14(Suppl 2), S7 (2013).

3. Kim, D., Langmead, B. \& Salzberg, S.L. Hisat: A Fast Spliced Aligner with Low Memory Requirements. Nat. Methods. 12, 357-360 (2015).

4. Pollier, J., Rombauts, S. \& Goossens, A. Analysis of Rna-Seq Data with Tophat and Cufflinks for GenomeWide Expression Analysis of Jasmonate-Treated Plants and Plant Cultures. Methods Mol Biol. 1011, 305-315 (2013).

\begin{abstract}
(c) (i) Open Access This article is licensed under a Creative Commons Attribution 4.0 International License, which permits use, sharing, adaptation, distribution and reproduction in any medium or format, as long as you give appropriate credit to the original author(s) and the source, provide a link to the Creative Commons license, and indicate if changes were made. The images or other third party material in this article are included in the article's Creative Commons license, unless indicated otherwise in a credit line to the material. If material is not included in the article's Creative Commons license and your intended use is not permitted by statutory regulation or exceeds the permitted use, you will need to obtain permission directly from the copyright holder. To view a copy of this license, visit http://creativecommons.org/licenses/by/4.0/.
\end{abstract}

(c) The Author(s) 2020 